Fride Lindstøl

Høgskolen i Sørøst-Norge

\title{
Tenk hvis - Om fiksjonserfaringer som utgangspunkt for refleksjon i lærerutdanningen
}

\section{Sammendrag}

I denne artikkelen settes søkelyset på norsk larerutdanning og på et arbeid med å utvikle et profesjonsverksted hvor sammenheng mellom teoretiske og praktiske perspektiver i utdanningen kan utforskes og drøftes. Profesjonsverksted kan forklares som en leringsarena hvor lererutdannere fra ulike fag samarbeider om å transformere overordnede mål for utdanning til høgskoledidaktiske aktiviteter og arbeidsformer. Studien tar utgangspunkt i feltnotater og fokusgruppeintervjuer fra en case der fire grupper med studenter har arbeidet med matematiske, norskfaglige og pedagogiske perspektiver knyttet til temaene klasseledelse og tilpasset opplcering. Et teoretisk og analytisk rammeverk fra drama- og teaterpedagogisk forskning bruker mediert fiksjon for å analysere muligheter til sammenheng mellom pedagogisk teori, fagdidaktiske valg og praktisk lcererarbeid. Resultatet fra analysen av studentgruppers intervensjon med tre ulike fiksjonsformer viser hvordan aktivitetene bidrar til sammenheng på ulikt vis: Simulering tilbyr mulighet til å øve og trene på delferdigheter og profesjonsspesifikke situasjoner. Narrative og poetiske fiksjonsformer bidrar til å involvere personlige erfaringer i lceringsarbeidet og utvide studentenes didaktiske repertoar. Refleksive fiksjonsformer gir mulighet til å identifisere seg med ulike roller og perspektiver og trene på å bruke et profesjonsspråk for å analysere praktisk lcererarbeid. Studien er et bidrag til å utvikle og forske på høgskolepedagogiske læringsrom mellom skole og lærerutdanning som kan bidra til å skape sammenheng mellom skolefag, pedagogikk og praktisk larerarbeid.

Nøkkelord: lcererutdanning, høgskolepedagogikk, profesjonsverksted, larerrolle, fiksjon, mediering

\begin{abstract}
In this article we look into Norwegian teacher training and the development of an educational workshop where the link between theoretical and practical perspectives in education can be explored and discussed. This workshop can best be described as an arena for teaching where teacher trainers who teach different subjects cooperate on transforming overriding educational goals into didactic activities and methods of teaching their college students. The course is based on field notes and interviews with focus groups from a case where four
\end{abstract}


groups of students worked with class leadership and adapted learning in the subject areas of Mathematics, Educational Science and Norwegian. A theoretical and analytical framework from research into educational drama and theatre uses the medium of fiction as a way of analysing the possible parallels between educational theory, didactic choices and practical teaching. The groups worked with three different forms of fiction. The result of the analysis of this intervention shows how these activities are linked: Simulation opens up for the possibility of practicing different skills and profession-specific situations. Poetical and narrative forms of fiction encourage the involvement of feelings and personal experiences in teaching, while also offering a common aesthetic framework in the staging of complex concepts. Reflexive forms of fiction make it possible to decentre and acquire a professional language when analysing one's teaching practice. The course may contribute to developing research into the relationship between educational science at the levels of the school, the college and teacher training, which may in turn link practical teaching, educational science and the different school subjects.

Key words: teacher training, educational science at college level, educational workshop, role of the teacher, mediated fiction

\section{Innledning}

Det å lære andre å bli lærere, er en sammensatt oppgave og profesjon. Det forventes at lærerutdannere skal produsere vitenskapelige artikler, ha en nær relasjon til praksisfeltet og samtidig gi studentene en variert, forskningsbasert og praksisnær undervisning. Fordi lærerutdannerne underviser om å undervise forventer både studenter og praksislærere at lærerutdannere modellerer yrket de utdanner for (Ulvik \& Smith, 2016, s. 63). Som en kontrast til disse forventningene viser forskning på lærerutdanningen i Norge en manglende sammenheng mellom fagstudium og praksisopplæring og mellom skolefagene og pedagogikkfaget. (Munthe \& Haug, 2010, s. 189). Flere studier viser også at lærerutdanningen i for liten grad forbereder studentene på sentrale utfordringer i lærerrollen og læreryrket (Hammerness, 2012, s. 21; Heggen \& Raaen, 2014; Munthe \& Haug, 2010; Østrem, 2008). En evaluering av lærerutdanningsreformen viser et behov for en bedre integrering av fag, fagdidaktikk og praksisopplæring (Følgegruppen for lærerutdanningsreformen, 2015, s. 20-23). Rapporten viser at studenter etterlyser mer profesjonskunnskap, større praksisnærhet og mer realisme i pedagogikkundervisningen og fagdidaktikken. Den samlede forskningen peker på et behov for empiriske studier som fokuserer på hvordan lærerutdannere kan undersøke og utvikle egen undervisningspraksis (Grossman, Hammerness, \& McDonald, 2009; Qvortrup \& Keiding, 2014). En måte å få til en slik kobling på er at lærerutdannere 
modellerer praktisk undervisning og viser hvordan teorien kan brukes til metakommentarer og analyse av egen undervisning (Ulvik \& Smith, 2016, s. 7476). Et ønske om å utvikle og forske på egen praksis som lærerutdanner har motivert arbeidet med profesjonsverkstedet som presenteres i denne artikkelen.

Profesjonsverkstedet kan beskrives som en læringsarena hvor et flerfaglig team med lærerutdannere (fra pedagogikk, drama, norsk, matematikk) hadde et felles ønske om å undersøke, dele og transformere mål og visjoner for grunnskolelærerutdanning til læringsressurser og læreprosesser (Lindstøl, Bakke, \& Moe, 2015, s. 307). Profesjonsverkstedet har studenter på lærerutdanningen som primærmålgruppe, og sekundærmålgruppen er faglærerne som underviser på utdanningen. I etableringen av profesjonsverkstedet (2013) var formålet å kvalifisere studentene for yrkesutøving. Som et delmål for prosjektet ønsket lærerteamet å skape en arena for å utvikle og teste ut aktiviteter, medierende redskaper og læreprosesser med ulike dramaturgiske kvaliteter som kunne styrke integrasjonen mellom teori og praksis, primært i undervisningen på campus. I piloteringen av prosjektet ble derfor studenter bedt om å rapportere hva slags aktiviteter som i størst mulig grad la til rette for slike transformasjoner. I den forbindelse fremhevet studentene aktiviteter der de skulle forestille seg roller og situasjoner. Dette gikk ut på å undersøke hvordan ulike fiksjonsformer kunne fungere som medierende redskaper for deltagernes samarbeid og kommunikasjon. Måten fiksjonen ble utformet og virket på, så ut til å tilby særegne former for aktivitet og refleksjon som virker interessante når det gjelder å skape sammenheng og integrasjon. Som forsker og en av deltagerne i lærerteamet ønsket jeg få en bedre forståelse av hvilken måte fiksjon kunne adapteres og brukes i en lærerutdanningskontekst: Hvordan forklarer studentene fiksjonserfaringer? Er det forskjellige erfaringer knyttet til ulike fiksjonsformer? Spørsmål som oppsto i piloteringen, er utgangspunkt for studien som presenteres i denne artikkelen.

Datamaterialet for studien er fra undervisning av grunnskolelærerstudenter i profesjonsverkstedet høsten 2015, mellom studentenes første og andre praksisperiode. Planlegging og gjennomføring av forløpene er gjort i lærerteamet, mens innsamling av data, analyse og drøfting er gjort av meg som lærerutdanner og forsker. I metodedelen viser jeg hvordan erfaringer og refleksjoner knyttet til fiksjonsformer med ulike kvaliteter førte til utledning av følgende problemstilling:

På hvilken måte kan erfaring med ulike fiksjonsformer bidra til at et utvalg lcererstudenter reflekterer over sammenhenger mellom praktisk lcererarbeid og teoretiske perspektiver i utdanningen?

For å undersøke den eventuelle sammenhengen mellom fiksjonerfaringer og refleksjon utviklet jeg et casedesign hvor tre fiksjonsformer (redskaper) med ulike kvaliteter ble systematisk utprøvd og analysert i profesjonsverkstedet: 
simuleringer, refleksive fiksjonsformer og narrative/poetiske fiksjonsformer (Neelands, Goode, \& Mørch, 2000, s. 7-13). Fiksjonsformene er kjent og etablert i dramapedagogikken, men måtte av lærerteamet adapteres til en lærerutdanningskontekst. Kort forklart (mer om dette i teorikapittelet) ble studentenes arbeid med simuleringer en måte å prøve ut situasjoner som lignet på lærerens arbeid i klasserommet. Et eksempel er å simulere et lengdesnitt av undervisningsforløp, for eksempel oppstart, helklassesamtaler, utviklingssamtaler og faglig argumentasjon mellom lærere. Simuleringsformen kan karakteriseres som et medierende redskap for å prøve ut virkelighetsnære og autentiske situasjoner og roller (Neelands et al., 2000, s. 26). Refleksive fiksjonsformer (Neelands et al., 2000, s. 57) ble prøvd ut i to former: Den ene formen var ved bruk av såkalte teoretiske "linser", hvor studentene trente på å analysere praktiske situasjoner (i form av case, filmklipp, lydopptak, simuleringer) gjennom å bruke på forhånd bestemte teoretiske begreper eller profesjonsspråk. Den andre formen for refleksiv fiksjonsform var at studentene skulle identifisere seg med forestilte perspektiver og roller (foreldre og elever med ulik bakgrunn). Ut ifra den på forhånd bestemte fiktive rollen skulle studentene forsøke å tenke, observere og analysere situasjonen empatisk, det vil si ut ifra et annet perspektiv enn sitt eget. Som en tredje form for fiksjon ønsket jeg å undersøke narrative og poetiske fiksjonsformer (Neelands et al., 2000, s. 27, 40). Denne fiksjonsformen inkluderer virkemidler som metaforer, symboler, kontraster og analogier, og vil i større grad tilby studentene estetiske uttrykksformer, som for eksempel muntlig fortelling, lyd/musikk, romlige installasjoner og poetiske korttekster (Lindstøl \& Bakke, 2016, s. 1, 3, 4, 32, 45, 37).

I planleggingsfasen samarbeidet lærerteamet om å utvikle læringsressurser som på ulike vis tok utgangspunkt i de tre ovennevnte formene for fiksjon. Fiksjonsformene ble satt sammen til et undervisningsforløp som tok utgangspunkt i et fagovergripende tema i lærerutdanningen: klasseledelse og tilpasset opplcring. Det samme forløpet ble prøvd ut i fire ulike studentgrupper (se metodedel for mer informasjon). Forløpet var stramt ledet og strukturert, slik at alle studentene fikk erfaring med tre fiksjonsformer. I neste delkapittel plasseres studien ut ifra relevant forskning på lærerutdanning. Videre presenteres teoretisk bakgrunn, metode og resultatene av analysen. Til slutt drøftes resultatdelen sett ut ifra teoriutvalget og relevant forskning.

\section{Integrasjon i lærerutdanningen}

Lærerutdanningen er sammensatt av mange fagfelter, og forskning viser at flere perspektiver står i motsetning til hverandre (Grimen, 2008, s. 190). Målet er at utdanningen skal være integrert og gi god sammenheng mellom teori og praksis og mellom skolefag og pedagogikk (Munthe \& Haug, 2010, s. 189). 
Enkeltstudier viser at det ikke er samsvar mellom studenter og lærerutdanneres vurdering av innholdet i utdanningen. Studentene rapporterer mangel på studentaktive arbeidsformer, mens lærerutdannerne selv karakteriserer egen undervisning som både aktiviserende og variert (Munthe \& Haug, 2010, s. 200). Forskning viser også at lærerutdannere kan være skeptiske til å lære bort spesifikke strategier og metoder (Hammerness, 2012). Peder Haug kommenterer dette når han sier at fagene i lærerutdanningen motsetter seg å dra inn det praktiske. En av årsakene er at det å fokusere på metoder og konkrete strategier ofte oppfattes som instrumentalisme (Haug, 2013, s. 172-178; Skjervheim, 1992). Ulvik og Smith sin studie fra 2016 konkluderer med at studentene trenger innspill til hva de skal gjøre i et klasserom, men også hjelp til å se klasserommet i et større og samfunnsmessig perspektiv (Ulvik \& Smith, 2016, s. 75).

En strategi for å styrke studentenes læreridentitet, som Østrem (2009) foreslår, består i å arbeide mer bevisst med et profesjonelt yrkesspråk: "Utvikling av vitenskapelige begreper setter oss i stand til å løsrive oss fra det situasjonsspesifikke, partikulære og konkrete og tenke på et mer abstrakt og generalisert nivå” (Østrem, 2009, s. 372). Østrem mener at lærerstudenter bærer med seg en antakelse om hva lærerrollen og yrkesutøvelsen består av, som ofte bygger på erfaringer fra egen skoletid. Hun understreker at lærerutdanningen er en viktig arena for å utvikle yrkesspråk som kan bidra til at det blir bedre sammenheng mellom fagspråk og praksis og mellom studentenes forforståelse og mål og visjoner for profesjonen (Østrem, 2009, s. 381). Erling Lars Dale poengterte at lærerutdanningen må hjelpe studentene til å bruke teori som basis for praktiske og didaktiske valg (Dale \& Høy Hansen, 1998). En utfordring for lærerutdanningen er derfor å utvikle arenaer på campus der slike problemstillinger utforskes og drøftes (Hammerness, 2012). Lampert kaller slike rom et hybrid space, et læringsrom mellom skole og universitet som kan utfordre både teoretiske og praktiske perspektiver i lærerutdanningen (Lampert, 2001). En konkretisering av et hybrid space kan være ulike former for læringslaboratorier eller profesjonsverksteder, som i denne studien. Slike arenaer er allerede etablert i flere profesjonsutdanninger, som for eksempel The change laboratory, som er et aktivitetsteoretisk orientert laboratorium hvor ulike yrkesgrupper og praksiser samhandler gjennom å bruke ulike aktiviteter og artefakter (Haapasaari, Engeström, \& Kerosuo, 2014) . Andre eksempler er lesson studies (Munthe \& Rogne, 2015) og simulatorer (Horntvedt \& Arnseth, 2013). Profesjonsverkstedet bygger på drama- og teaterfaglig forskning som tematiserer hvordan forestilte og symbolske handlinger og refleksjon styrker deltakernes opplevelse av mening og læring (Dewey, 2005; Krøgholt, 2001; Rasmussen, 2013; Rasmussen \& Kristoffersen, 2014). I neste delkapittel forklares hvordan forestilte og symbolske fiksjonsformer kan forstås som medierende redskaper som kan gi form til et faglig innhold innenfor en lærerutdanningskontekst. 


\section{Teoretisk bakgrunn: Fiksjon som medierende redskaper}

Begrepet fiksjon kommer fra det latinske ordet fingere, som betyr "å finne på, dikte opp eller late som”. For eksempel er det vanlig å snakke om den distanse som fiksjonen kan gi, og som gjør det mulig ”å leve seg inn i og forstå situasjoner og relasjoner som ellers kunne oppleves altfor nære, intime og kanskje truende” (Braaten \& Erstad, 2000, s. 76; Østern, 2014, s. 170). I et performativt syn på virkeligheten inkluderes fiksjonshandlinger og forestillinger som en del $a v$ vår virkelighet (Fischer-Lichte, 2008). Kjølner bruker metaforen Theatrum Mundi for å forklare performativitet, og påpeker at metaforen har ført til at "der er blevet en stadig kortere vej mellem virkelighed og billedlig reference" (Kjølner, 2007, s. 14). I et performativt perspektiv blir det å forestille seg sett på som en mulighet til å skape, tenke og å lære: "Vi er avhengig av våre forestillingsevner for i det hele tatt å begripe verden rundt oss. Fiksjonen er ett av denne evnens uttrykk” (Gladsø, Gjervan, Hovik, \& Skagen, 2005, s. 182). Det å forestille seg det som ikke er - men muligens kunne være - overskride og tenke nytt, føle, handle og bruke språk på nye måter blir en didaktisk inngang til å gi form og språk til et faglig innhold. Samtidigheten som oppstår mellom å være seg selv og være en annen har grenseoverskridende kvaliteter fordi de to virkelighetene smelter sammen gjennom fiksjonen (Bolton, 1984). Med fiksjonens beskyttende lag kan nye og mer uvante uttrykk prøves ut og forankres. Dette vil kunne bearbeide sjenanse og utvikle kommunikativ kompetanse, øke mot, selvforståelse - fra en emosjonell og erfart basis (Rasmussen \& Kristoffersen, 2014). Fiksjon som læringsressurs kan derfor tilby en didaktisk mulighet til å skape, utforske og formidle mening gjennom dramatiske metoder og medier, som for eksempel muntlig fortelling, dramatisering og simulering.

I klassisk forstand knyttes fiksjonen til den mimetiske etterligning/imitasjon, som bygger på et klart skille mellom empirisk og symbolsk virkelighet. Det vil si at selv om en rolle eller situasjon imiterer og ligner på virkeligheten, er det likevel en symbolsk versjon. En symbolsk versjon kan ha ulike kvaliteter: fra det poetiske og stiliserte til det mer realistiske og autentiske (Gladsø et al., 2005, s. 25; Rasmussen, 2008). Dewey understreker at valg av medium fokuserer læreprosessen og knytter lærestoffet til elevenes forforståelse og fantasi (Rasmussen \& Kristoffersen, 2014, s. 41-43). Mediet intensiverer og transformerer kunnskaper og erfaringer som finnes i læringsfelleskapet (Lindstøl, 2014; Rasmussen, 2013; Rasmussen \& Gjærum, 2012). Noen medier synes som nevnt tett på virkeligheten, andre krever mer tolkningsarbeid og ny kunnskap om formalestetiske kjennetegn som for eksempel dans, muntlig fortelling og dramatisering.

Når det gjelder Deweys forståelse av medium, ligner det på et sentralt begrep fra sosiokulturell læringsteori: mediering. Begrepet mediere viser til at vi fortolker verden gjennom redskap som er forankret i forskjellige sosiale 
praksiser (Säljö, 2001; Vygotskij, 1986; Wittek, 2012). Psykologiske og fysiske redskaper fungerer som strukturerende ressurser som gjør det mulig for deltakere i sosiale praksiser å tolke og handle kompetent i nye situasjoner. Ved å knytte fiksjon til medieringsbegrepet kan man si at ulike fiksjonsformer blir en form for redskap gjennom valgt medium (Barone \& Eisner, 2012, s. 62; Dewey, 2005, s. 244). Fiksjonens innhold og form kan derfor beskrives som uatskillelige, ikke minst fordi fantasien stimuleres i møte med det materialet som skal brukes, enten det er kropp, stemme, rom, eller figurer (Gladsø et al., 2005, s. 182). Det forestilte perspektivet og det valgte mediet kan transformere hverdagsopplevelser, hverdagsspråk og egen forforståelse til en kollektiv, fagspesifikk og symbolsk tolkning. Dette vil være kollektivt fordi studentene samarbeider innenfor den samme fiktive virkeligheten, individuell fordi hver enkelt bidrar med egen forforståelse (Dewey, 2005; Heggstad, Eriksson, \& Rasmussen, 2013; Rasmussen, 2013). Neelands er en av mange som har utformet et utvalg dramatiske metoder som også kan forklares som konvensjoner som bruker ulike medier for samarbeid og interaksjon (Neelands et al., 2000). Konvensjonene kan forstås som mediert fiksjon som åpner opp for ulike måter å ramme inn aktiviteter i et profesjonsveksted. Et utvalg dramatiske konvensjoner blir av Neelands kategorisert som simulering, narrative/poetiske fiksjonsformer og refleksive fiksjonsformer.

Neelands forklarer simulering som "situasjoner fra det virkelige liv fremstilles på en sådan måte at fokus sættes på prioritering av ressourcer, afgørende beslutninger, problemløsning” (Neelands et al., 2000, s. 26). Neelands kategoriserer simulering som en del av kontekstskapende handling som gjør det mulig for en gruppe å leve seg inn i en autentisk situasjon og avklare deltakernes oppfatning av kontekstens premisser eller problemstillinger. Selv om simuleringene ligner på situasjoner og roller i klasserommet, vil disse aktivitetene regisseres og rammes inn gjennom hvordan fiktive steder, rom, konflikter og roller planlegges og spilles ut.

Refleksive fiksjonsformer viser til aktiviteter hvor deltagerne forestiller seg og iscenesette den andres blikk, tanke eller tolkning. Neelands beskriver denne formen for dramatiske handlinger som å tre tilbake fra handlingen og gjøre status over de betydninger eller spørsmål som er kommet frem, få et overblikk over handlingen og knytte bemerkninger og refleksjoner til den (Neelands et al., 2000, s. 57). Han sier videre at aktivitetene kan gi mulighet til å oppdage og ta høyde for forutinntatthet, fordommer og ulik tolkninger av den samme hendelsen, anspore til å undersøke for eksempel hvordan sosial status, kjønn og kulturell bakgrunn skaper flerstemmighet og konflikter innenfor en sosial (lærings)situasjon eller gruppe. Fiksjonsformen kan eksemplifiseres med aktivitetene vitneobservasjon og flerstemmige beskrivelser (Lindstøl \& Bakke, 2016, s. 144-145, 210-211). Denne formen for fiksjon vil også romme ulike lytterposisjoner og leseroller, noe som også er en sentral del av didaktiske strategier i norskfaget (Børresen, 2016). 
Narrative og poetiske fiksjonsformer skiller seg fra simuleringsaktiviteter ved at studentene uttrykker seg gjennom medier og redskaper som ikke imiterer autentiske og hverdagslignende situasjoner. Fiksjonsformene setter begreper, handlinger og holdninger i spill gjennom å bruke symbolske og poetiske medier, som for eksempel muntlig fortelling, dramatisering, foto, musikk og ulike skriftlige uttrykksformer (for eksempel lister, dagbok, brev). Formen inkluderer også stiliserte kroppslige og non-verbale uttrykk og ulike muntlige sjangere (Børresen, 2016, s. 27-57; Neelands et al., 2000, s. 15, 18, 31, 47). Fiksjonsformene benytter seg av uttrykksformer fra teater, populærkultur og litteratur, og bruker virkemidler og medier som i større grad enn simulering rommer estetiske uttrykksformer. Narrative og poetiske fiksjonsformer kan ifølge Neelands brukes til å rette fokus mot betydningsfulle situasjoner eller konflikter og gi plass til utforsking av sentrale symboler og metaforer i læringsforløpet. Begrunnelsen for en slik fiksjonsform er å få et nytt blikk på situasjonen eller konteksten og å åpne for et følelsesmessig engasjement og identifikasjon (Neelands et al., 2000, s. 40).

\section{Metode: design og innsamling}

Denne studien inngår i prosjektet: Tenk hvis - Profesjonsverkstedet i GLU (Lindstøl et al., 2015). Prosjektet er godkjent av NSD og startet våren 2013. I piloteringen deltok det ca. 400 studenter (2013-2014), der de etter hver undervisningsøkt svarte på en spørreundersøkelse som tematiserte de ulike aktivitetene de hadde vært med på. Metodisk kan studien beskrives som en klassisk casestudie forstått som "A spatially delimted Phenomenon (a unit) observed at a single point in time or over some period of time" (Gerring, 2007, s. 19). Det samlede empiriske materialet inneholder to datakilder innenfor kvalitativ forskning: observasjoner/feltnotater og gruppeintervjuer. Innsamling av data ble gjort en uke før studentenes første praksisperiode høsten 2015. Datagrunnlaget er fra 3 dager (6 undervisningstimer pr. dag) som ble gjennomført i fire ulike studentgrupper (G1, G2, G3, G4, til sammen 100 studenter). Studentene er førsteårs lærerstudenter på bachelorprogrammet fra 5.10. trinn, to grupper med matematikk som fordypningsfag og to med norsk. Utgangpunktet for profesjonsverkstedet var matematiske, norskfaglige og pedagogiske perspektiver med utgangpunkt i temaene klasseledelse og tilpasset opplcering. Alle studentene fikk erfaring med de tre fiksjonsformene, selv om de i noen episoder ble delt i grupper hvor en gruppe iscenesatte en situasjon, mens andre observerte, ofte gjennom å bruke refleksive fiksjonsformer. Forsker og to faglærere var til stede i alle øktene. Undertegnede skrev feltnotater som ble diskutert i lærerteamet etter hver undervisningsøkt. I etterkant av tre dagers verksted ble det i hver gruppe gjennomført fokusgruppeintervju med 8 studenter fra hver klasse. Kriterene for utvelgelse av informanter var kjønn (4 kvinner og 
4 menn) og ulik alder (ca. halvparten fra 20-25 og halvparten over 30 år). Dette var for å inkludere både studenter som kom rett fra videregående skole og studenter som hadde mer erfaring fra arbeidsliv, andre studier, foreldreskap og voksenliv. Deltakelsen var basert på informert samtykke fra studenter. Intervjuene ble tatt opp med digital opptaker og transkribert. Det ble brukt en intervjuguide som tok utgangpunkt i øktagenda og feltnotater fra profesjonsverkstedet.

\section{Analysestrategier}

I analysen av datamaterialet ble det viktig å finne en analysemetode som best mulig kunne utforske sammenhengen mellom studentenes erfaringer med fiksjonsformene på den ene siden og deres refleksjon rundt dette på den andre. I studien vil jeg derfor kombinere en summativ og teoridrevet innholdsanalyse (Fauskanger \& Mosvold, 2014, s. 135; Hsieh \& Shannon, 2005). En summativ innholdsanalyse kan brukes til å finne ut hvilke ord og begreper studentene fokuserte på, slik det kommer til uttrykk i transkripsjonene (Fauskanger \& Mosvold, 2014, s. 130-135). Antall forekomster av et bestemt ord kan si noe om hvor mange som deler et perspektiv eller stikkord. Det var derfor viktig å søke etter ord som er aktuelle ut ifra mitt forskningsspørsmål: fiksjon, refleksjon, erfaring, teori, praksis, læerer, utdanning, sammenheng. Fordi jeg fikk få treff ved å søke etter begrepet fiksjon, søkte jeg etter andre begreper som jeg tolket som relevante konnotasjoner. I stedet for fiksjon brukte studenter begreper som: $\AA$ forestille, øve, prøve/teste ut, tenke som, simulere, iscenesette, identifisere seg med, rolle, dramatisere, perspektiv, være/spille. Disse begrepene faller inn under overbegrepet fiksjon, et sentralt begrep i denne studien. Ved hjelp av søkeordene fikk jeg en oversikt over hvor i materialet det ble snakket om fiksjonsaktiviteter. På denne måten fikk jeg en oversikt over hvilke begreper, erfaringer og eksempler studentene vektla i refleksjonene sine, noe som bidro til å utvikle tre kategorier:

a) Utprøving og trening

b) Sammenheng mellom praktisk lærerarbeid og pedagogisk teori

c) Relasjonell kompetanse

I neste fase gjorde jeg en teoridrevet innholdsanalyse, hvor jeg systematiserte feltnotater og de transkriberte intervjuene sett ut ifra de tre fiksjonsformene som var utgangspunkt for aktivitetene i profesjonsverkstedet. En slik analyseform blir av Hsieh og Shannon kalt "directed content analysis" - på norsk teoridrevet innholdsanalyse (Fauskanger \& Mosvold, 2014, s. 135; Hsieh \& Shannon, 2005, s. 5). En slik analyse kan ses på som en deduktiv kategorisering, det vil si at forskeren har noen teorier som skal testes ut (Hsieh \& Shannon, 2005, s. 5). For 
å bruke en slik tilnærming til analyse av transkripsjonene av intervjuene, kan man ta utgangspunkt i tidligere forskning og teorier som er relevant for prosjektet. Hovedmålet kan være å validere eller videreutvikle et eksisterende rammeverk - noe som er relevant i denne studien, hvor jeg ønsker å undersøke og adaptere ulike former for mediert fiksjon i en lærerutdanningskontekst. Transkripsjonene ble derfor kategorisert gjennom de tre fiksjonsformene. I siste fase av analysen sammenlignet jeg kategoriene fra den summative analysen med resultatene av den teoridrevne analysen. Det viste seg at kategoriene som ble utviklet i den summative innholdsanalysen, hadde sammenheng med studentenes erfaring med fiksjonsformer med ulike kvaliteter. En slik sammenkobling antyder at fiksjonsformene bidrar på ulikt vis til at studentene reflekterer over teoretiske og praktiske sammenhenger i utdanningen. Tabellen nedenfor viser hvordan kategorier fra den summative analysen og den teoridrevne analysen kobles sammen:

Tabell 1: Kategorier fra summativ innholdsanalyse koblet med den teoridrevne innholdsanalysen.

\begin{tabular}{|l|l|l|}
\hline 1. Simulering & 2.Refleksive fiksjonsformer & $\begin{array}{l}\text { 3.Poetiske og narrative } \\
\text { fiksjonsformer }\end{array}$ \\
\hline $\begin{array}{l}\text { a) utprøving og trening } \\
\text { b) sammenheng mellom praktisk } \\
\text { lærarbeid og pedagogisk teori }\end{array}$ & $\begin{array}{l}\text { a)utprøving og trening } \\
\text { b)sammenheng } \\
\text { mellom praktisk lærerarbeid og } \\
\text { pedagogisk teori } \\
\text { c) relasjonell kompetanse }\end{array}$ & $\begin{array}{l}\text { a) utprøving og trening } \\
\text { c)relasjonell kompetanse }\end{array}$ \\
\hline
\end{tabular}

I neste del presenteres studiens begrensninger, før resultatene presenteres og tolkes ut ifra ovennevnte kategorier.

\section{Studiens begrensninger}

Min posisjon i denne studien kan sies å være en insider, det vil si en person som Kvernbekk forklarer som "en som på grunn av sin spesielle og privilegerte posisjon innehar - eller antas å inneha - en kunnskap som andre ikke har" (Kvernbekk 2005 s. 18). Fordi jeg selv er en del av lærerteamet som utvikler profesjonsverkstedet, kan man si at mine roller som lærerutdanner har en privilegert tilgang til egne "intensjoner, persepsjoner, vurderinger, aktiviteter" (Kvernbekk, 2005, s. 31). En slik posisjon kan kritiseres for å skape manglende distanse og avstand til datamaterialet. En insider-posisjon har epistemologiske implikasjoner som stiller store krav til systematisk analyse og datatransparens. I denne casen blir outsider-perspektivet representert ved å trekke inn studentenes perspektiv, men også ved å legge frem analysen til kritisk vurdering for eksterne fagpersoner. Jeg har også vektlagt både en summativ og teoretisk innholdsanalyse, noe som kan bidra til koherens mellom studentenes erfaringer med fiksjonsformene og refleksjon i etterkant. For å sikre transparens har de transkriberte intervjuene og eksempler fra observasjonene fått stor plass i 
presentasjon av resultater. I fremtidig forskning vil flere komparative caser fra arbeid i profesjonsverkstedet og samarbeid med eksterne følgeforskere styrke prosjektet.

\section{Resultater}

I dette avsnittet vil ytringer fra kategoriene a) utprøving og trening, b) sammenheng mellom praktisk lærerarbeid og pedagogisk teori og c) relasjonell kompetanse bli presentert og tolket opp mot de tre fiksjonsformene. Hver ytring er merket med fag (norsk og matematikk), gruppe (G1-G4) og årstall for intervjuene. Fiksjonsformene introduseres med eksempler fra aktiviteter i profesjonsverkstedet.

\section{Simulering}

Som en del av arbeidet med tema klasseledelse og tilpasset opplaring simulerte studentene situasjoner som lignet på lærerens arbeid i klasserommet. Et eksempel var å simulere lengdesnitt av didaktiske forløp, for eksempel oppstart, overgang mellom aktiviteter og avslutning. Studentene simulerte også utviklingssamtaler, deler av foreldremøter og faglige diskusjoner mellom lærere, skoleledere og foreldre. Da simuleringsaktiviteter ble introdusert fikk studentene instruksjoner og en fiksjonskontrakt for samspill og interaksjon. Fiksjonskontrakten inneholdt informasjon om hvor de var, hvem de var, hva som var bakgrunn for situasjonen, hva de visste om de andre som er til stede. For å tydeliggjøre en konflikt eller faglige motsetninger ble det tatt utgangspunkt i skriftlig case, observasjonsskjema og rollekort. Rollekortet ga opplysninger om rollens faglige, sosiale og kulturelle forforståelse, (jf. Neelands et al., 2000, s. 26) slik at ulike viljer, intensjoner og tolkninger kunne virke sammen i et simulert samspill.

Studentene vurderte simulering som viktig for å øve seg på praktisk lærerarbeid. Det å øve seg ble i intervjuene forklart som å instruere, samtale og presentere fagstoff på ulike måter. Disse ytringene er kategorisert som utprøving og trening i analysen. Flere studenter presiserer at de gjennom simuleringene fikk testet ut og fikk tilbakemelding på ulike muntlige strategier som læreren bruker som en del av den praktiske klasseledelsen: fortelle, gi fremovermeldinger, lede en klassesamtale, stille gode spørsmål (Børresen, 2016). Muntlige ferdigheter forklares blant annet som en måte å trene på å tilpasse muntlige strategier til mottakere og kontekst: En student sier: Gjennom å teste ut ulike lererroller skjønte jeg hvordan man kan ordlegge seg og bruke kropp og stemme i samspill med mottaker og miljø (Norsk, G2, 15). En annen student uttaler: simuleringene gjorde at jeg er mer mottakerbevisst enn jeg var før (Mat G4, 15). Flere studenter understreket at utvikling av muntlige ferdigheter krevde øving og deltrening. For meg var det viktig å øve på 
overganger mellom ulike aktiviteter for å forklare hvorfor vi gjør det vi gjør for elevene. Ofte er det instruksjonene og beskjedene som er uklare, mens aktiviteten er ganske godt forberedt. Jeg må øve på å tilpasse språket til ulike aldersgrupper (Mat, G4,15). Måten studentene uttaler seg på, antyder at det er behov for læringsaktiviteter hvor studentene kan prøve ut og få tilbakemelding på praktisk lærerarbeid og muntlige strategier. Simuleringene skiller seg fra trening i ordinær praksis fordi man kan fokusere på, gjenta og analysere spesifikke deler av et forløp. Studentene kobler erfaringen med simuleringene til egen utvikling og progresjon, for eksempel ved å bruke formuleringer som jeg må øve på.

Nesten samtlige studenter uttalte at det å kunne prøve nye formidlingsformer og didaktiske strategier motiverte dem til å gjøre det samme i ordinær praksis. Et eksempel på ytring fra denne kategorien er: For meg er det viktig å kunne prøve og feile før jeg går ut i praksis. Det ga meg en følelse av hva jeg kan forvente. (Norsk, G1, 15). En annen student sier: Det er både utfordrende og nødvendig å prøve ut ulike situasjoner. Det å late som gir rom for lcerdom og refleksjon (Mat, G4, 15). Det å trene på ulike situasjoner og praktiske ferdigheter vurderes som viktig for utvikling av praktisk klasseledelse, men også for presis og målrettet observasjon: Jeg føler at det har gjort meg tryggere på hva jeg skal se etter blant annet klasseledelse og tydelighet hos lareren (Norsk, G2 1). En annen student bekrefter dette: Jeg har ikke visst hva jeg skal se etter, det føles som jeg har fått noen nye læerer-briller (Mat, G4, 15). Disse utsagnene kan tyde på at det å selv prøve ut de ulike situasjonene kan bidra til et mer profesjonelt og fokusert blikk i praksis.

En gruppe matematikkstudenter poengterte at de synes det var vanskelig å identifisere seg med rollene i simuleringsaktivitetene fordi de opplevdes lite autentisk sett ut ifra klasserommets virkelighet: Jeg synes det var vanskelig å liksom vare larer eller elev, jeg ble mer opptatt av hvordan det så ut utenfra, at det skulle væere litt morsomt for de andre. Jeg klarer ikke helt å tro på meg selv som lerer for mine medstudenter, jeg klarer ikke late som (Mat, G3, 15). Andre studenter sier det motsatte, at simuleringen bidrar til beskyttelse, noe som gjør det lettere å prøve ut muntlige og didaktiske strategier: Jeg tror det var veldig viktig for min lereprosess at jeg fikk prøve ut de forskjellige klasseromssituasjonene, ellers kommer jeg ikke til å tørre i praksis (Norsk, G1, 15). Begge perspektivene er representert i utvalget. Når jeg sammenligner feltnotatene med studentenes ytringer, ser det ut som bakgrunn og faglig begrunnelse for simuleringen ikke alltid har blitt tydelig nok kommunisert, nærmere bestemt hvilke ferdigheter/situasjoner som øves på og hvordan simuleringen er relevant for temaet klasseledelse og tilpasset opplæring. Flere studenter uttaler at klare regler for samspill og tydelig kobling til det tematiske utgangspunktet gjør det enklere å identifisere seg med situasjonen og rollen. Et eksempel som forsterker denne tolkningen, er en simulering som ble koblet til formativ vurdering: Når jeg prøvde de ulike didaktiske oppstartsformene så jeg 
hvordan jeg kunne lede en formativ vurderingssituasjon. Oppstartsformene ga ulike muligheter for meg som klasseleder - jeg kunne bruke materiellet til å stille ulike typer spørsmål som handlet om lerestoffet (Mat, G4, 15). Eksempelet ovenfor viser hvordan faglærer tydelig har introdusert hvilke pedagogiske begreper som settes i spill. En student fra samme studentgruppe bekrefter dette: Hadde ikke tenkt på at vurdering for laring er med hele tiden, hvordan jeg svarer på et spørsmål i klasse, presenterer læeringsmål, hvordan jeg svarer, hvordan jeg forklarer oppgavene (Mat, G4, 15). I eksemplene ovenfor ble erfaringen fra simuleringene et godt utgangpunkt for å reflektere over sammenheng mellom praktisk lererarbeid og pedagogisk teori.

Et annet eksempel som ble nevnt av flere i denne kategorien, var en simulering av en oppstart av et didaktisk forløp. Studentene fikk beskjed om å introdusere en rik brøkoppgave på tavla for en fiktiv 8. klasse og bruke oppstarten som utgangspunkt for klassesamtaler (Boaler, 2016).

I simuleringen skulle studentene forsøke å skape samtaler som a) aktiviserte flest mulig (lav inngangsterskel til temaet), b) bidro til å kartlegge forkunnskaper i klassen, c) støttet seg på relevante artefakter og materiell, d) koblet temaet brøk til elevenes hverdagsliv og referanser. I intervjuene i etterkant reflekterte studentene over sammenhengen mellom muntlige strategier og deres egen fagkunnskap: [...] og jeg skjønte at jeg var ganske god til å stille spørsmål og lytte til elevene, men jeg var altfor dårlig i brøkregning til å lede gode faglige samtaler (Mat, G3,15). I intervjuene understrekte flere studenter at de gjennom simuleringen fikk monitorert egne vekstpunkter som handlet om både fagkunnskap og egen undervisningsstil. Flere studenter understreket at for lavt faglig nivå i matematikk hindret muligheten til å få til rike klassesamtaler og presise fremovermeldinger: Meningen var at vi skulle snakke om brøkene ganske lenge. Og at elevene liksom skulle bruke materiellet på ulike måter. Men det stoppa opp og jeg ble litt usikker på hvordan jeg skulle spørre og hvordan materiellet skulle brukes sammen med mine spørsmål (Mat. G3, 15). Ytringen eksemplifiserer hvordan en simulering kan hjelpe studentene til å se sammenhengen mellom praktisk lærerarbeid, fagdidaktikk og egen fagkunnskap. Simuleringene satte studentenes faglige forforståelse $i$ spill og konkretiserte hva som må trenes på, leses og diskuteres. Min tolkning av studentenes vurdering av simuleringsaktivitetene kan oppsummeres i tre punkter:

1. Analysen viser at simulering gir studentene en mulighet til å deltrene og få tilbakemelding på egne didaktiske valg og muntlige strategier.

2. Hvordan simuleringen kontekstualiseres, har betydning for studentenes identifikasjon og utbytte av aktiviteten.

3. Erfaringer med simuleringene kan bidra til å formulere studentens praktiske og teoretiske vekstpunkter, noe som brukes som utgangspunkt for erfaringer i ordinær praksis. 
Flere studenter understreker at sammenheng mellom praktisk lærerarbeid og teori blir klarere når simuleringer kombineres med refleksive fiksjonsformer, noe som tematiseres i neste delkapittel. Studentuttalelsen er delt inn i to kategorier; utprøving og trening og relasjonell kompetanse.

\section{Refleksive fiksjonsformer}

Refleksive fiksjonsformer ble brukt i to former: Som teoretiske "linser" og som mentalt forestilte roller og perspektiver. De refleksive fiksjonformene ble brukt for å analysere praktiske situasjoner i form av simuleringer, film klipp, case (formidlet av faglærere som muntlige fortellinger) og lydopptak av samtaler med elever. Et eksempel på bruk av teoretiske linser var da studentene fikk utdelt fagbegreper som skulle brukes til å observere en simulert oppstart av timer: mediering, artefakter og redskaper, fagspråk og hverdagsspråk, strategisk og situasjonsbestemt klasseledelse, instruksjoner. Videre skulle hele klassen analysere simuleringen ut ifra sine begreper. Slik fungerte refleksive fiksjonsformer som teoretiske briller etter å ha observert en simulert utviklingssamtale (G2, feltnotat): Student 1: I samtalen bruker lereren et vurderingsskjema som artefakt, jeg synes ikke skjema bidrar til kommunikasjon mellom dem, det skaper bare utrygghet for eleven. Student 2: Læreren glemmer å instruere eller si noe om hvorfor de skal møtes og snakke sammen, ideen var jo å fokusere på framovermeldinger, ikke bare summativ vurdering. Student 3: Jeg synes læereren har for stram og ganske lukket strategisk ledelse, det er ikke rom for å snakke om hva elevene er opptatt av, det er ikke tid til åpne spørsmål. Når studentene sto fast i sine refleksjoner, eller begrepet ikke var tydelig forstått, modellerte faglærerne hvordan begrepene kunne gi form til analysen. I etterkant var studentene opptatt av at refleksive fiksjonsformer åpnet opp for å prøve ut og å øve på å bruke et profesjonsspråk. Studentenes ytringer i kategorien utprøving og trening ble dermed utvidet fra å handle om praktisk lærerarbeid (som i simuleringene) til å inkludere trening på å observere, analysere og begrunne ut ifra et profesjonsspråk: De teoretiske begrepene hjalp meg til å forstå hvilken funksjon teori har i utdanningen og hvordan man kan oversette de ulike begrepene for å få til god klasseledelse (Norsk, G1,15). Også i denne kategorien ble øvingen vurdert som forberedelse til ordinær praksis: Det er lettere å ha en samtale med praksislcerere fordi jeg har et språk som beskriver praktiske situasjoner på en profesjonell måte. (Norsk, G1, 15). Analyse gjennom spesifikke begreper førte til mer presise analyser av praktiske situasjoner fra klasserommet: Det var lererikt for å forstå begrepet differensiering og eksempler på rike oppgaver - alltid tenke flere muligheter og løsninger på samme oppgave. (Mat, G4,15). Flere nevner at fagspråket må brukes og øves på for å internaliseres; Første gang du sier begrepet, vokser det i munnen, og det føles fremmed. Etter hvert blir det en del av mitt lererspråk (Mat., G4, 15).

Analysen av studentuttalelsene viser at refleksive fiksjonsformer eksemplifiserer hvordan tolkning av den samme praktiske situasjonen forandres 
gjennom ulike linser eller teorier; hvordan forståelsen av situasjonen endrer seg gjennom å bruke ulike begreper (Mat., G3,15). Måten studentene uttaler seg på, kan tyde på at valg av fagbegreper fokuserer analysen slik at sammenheng mellom del og helhet, mikro- og makronivå kan tematiseres. Ved å kollektivt analysere den samme situasjonen gjennom ulike teoretiske briller som oppstår i en helklassesamtale, kan det oppstå en mulighet til å oppdage og ta høyde for forutinntatthet, fordommer og ulike tolkninger av den samme hendelsen (Neelands et al., 2000); Jeg hadde ikke trodd at måten jeg snakket på ekskluderte alle som ikke hadde lest Ibsen tidligere (Norsk, G1, 15). Det kan synes som refleksive fiksjonsformer fører til at studentenes forståelse av pedagogisk teori og pedagogiske fagbegreper settes i spill og kobles tettere til praktisk lærerarbeid. Samlet sett kan studentenes erfaring med refleksive fiksjonsformer tolkes som en måte å innvies i profesjonen, eller sagt med studentenes ord: bli en del av mitt laererspråk.

Den andre formen for refleksive fiksjonsformer var at studentene lyttet, leste eller observerte simulerte situasjoner, samtaler, fortellinger og lydopptak/filmklipp ved å mentalt forestille seg hvordan ulike perspektiver/roller tenker, føler eller handler. Gjennom å forestille seg en annen persons livsverden og språk skulle studentene "trene tanken” eller forsøke å dekode en situasjon ut ifra et annet perspektiv enn sitt eget. Et eksempel var når en faglig introduksjon til begrepet demokrati (for 8. trinn) ble observert ut ifra fem (fiktive) elever med ulik kulturell, faglig og sosial bakgrunn (beskrevet gjennom rollekort). Et annet eksempel var når et saksfremlegg på foreldremøte ble analysert gjennom ulike foreldreroller, med ulike holdninger, erfaringer og forventninger til skole. Flere studenter sa at de gjennom rollens blikk la merke til helt andre ord og handlinger enn de ville gjort ut ifra sitt eget perspektiv: Jeg ble på en måte tvunget til å sette meg inn i hvordan ulike elever kan oppleve samme situasjon (Norsk, G2.,15). En annen student sier at: Jeg larte å observere og evaluere på en ny måte. Før har jeg gjort det ifra mitt eget ståsted. (Mat., G3, 15). Det virket som det var et viktig didaktisk valg at den samme situasjonen ble observert ut ifra roller med ulikt faglig nivå, ulik elevidentitet og ulike erfaring/aktiviteter på fritiden: Ved å analysere situasjoner ut ifra forskjellige personer er det lettere å sette seg inn i ulike klasseromssituasjoner og elevroller. Faglig nivå er en faktor, sosiale roller og laringsstrategier er like viktig. (Norsk, G1, 15).

Min tolkning av studentuttalelsene er at de gjennom å analysere situasjoner ut ifra ulike roller reflekterer over hvordan praktisk lærerarbeid oppfattes ulikt ut ifra elevers og foreldres forforståelse. Fiksjonsformen bidro til å analysere oppgavetyper, eksempler og språk (helt ned til ordnivå) i samspill med mottaker og kontekst. Det fiktive perspektivet fungerte som en form for optisk linse for å dekonstruere situasjoner og narrativer: Jeg hadde ikke tenkt på at ordene jeg valgte kunne ekskludere flere foreldre. At jeg både må si det med fagspråk og 
hverdagsspråk for å nå flest mulig (Norsk G2, 15). Studentenes erfaringer med refleksive fiksjonsformer kan oppsummeres i to punkter:

1. Analysen viser at refleksive fiksjonsformer kan bidra til å trene på å bruke et profesjonelt språk for begrunne praktisk lærerarbeid og didaktiske valg. Ulike teoretiske begreper gir form til analysen, noe som hjelper studentene til å erfare hvordan teoretiske begreper bidrar til å dekonstruere og være kritisk til praksis.

2. Refleksive fiksjonsformer gir studentene en mulighet til å tenke, tolke og dekode en situasjon gjennom å identifisere seg med fiktive roller og perspektiver. Erfaringen forklares som en mulighet til å reflektere over hvordan elever og foreldre opplever en situasjon og språk ulikt.

I neste avsnitt vil studentenes erfaringer med poetiske og narrative fiksjonsformer presenteres og tolkes gjennom kategoriene utprøving og trening og relasjonell kompetanse.

\section{Poetiske og narrative fiksjonsformer}

Narrative og poetiske fiksjonsformer inkluderer som nevnt virkemidler som metaforer, symboler, kontraster og analogi (Neelands et al., 2000, s. 47). Fiksjonen medieres gjennom muntlig fortelling, lyd/musikk, romlige installasjoner og poetiske korttekster. Et eksempel på dette er fra introduksjonen av casens tema, tilpasset opplæring. Temaet introduseres ved å ta utgangspunkt i tekster og situasjoner fra Peer Gynt. Studentene iscenesatte deler av Peer Gynt sin historie gjennom ulike perspektiver: keiser, bondesønn, forfører, slavedriver, snylter, gjøgler og skrønemaker. Aktiviteter som for eksempel kroppen tar stilling (Lindstøl \& Bakke, 2016, s. 138-139), muntlig fortelling og poetiske lister (Lindstøl \& Bakke, 2016, s. 200-201) ble brukt for å erfare Peer Gynts selvfremstilling og identitetsreise. Kroppen tar stilling handler om å fysisk plassere seg i rommet ut ifra påstander som leses opp av leder. Påstandene tematiserer alt fra sentrale begreper (identitet, selvfremstilling), sjanger (om dramatikk, aristotelisk dramaturgi), virkemidler (løk som metafor) egne holdninger og erfaringer (Solveig er en romantiker, jeg tenker at jeg iscenesetter mange roller i mitt liv). Muntlig fortelling tar i bruk fortellermediets estetikk og teknikker. Poetiske lister er en nøktern, skriftlig formidling av hendelser, observasjoner, begreper eller kjennetegn. Et eksempel er listen som en student skrev som en tenkt 9. klassing sine refleksjoner om matematikkundervisningen: Jeg skjønner ikke hva brøk betyr. Jeg skjønner ikke hvordan brøk og prosent henger sammen. Jeg er redd for å vise lareren at jeg ikke forstår. Jeg tenker at jeg har larevansker. Jeg kan ikke få hjelp hjemme. Matematikkproblemer er arvelig. Listene kan tematisere lukt, smak, følelser, minner og bilder, og egner seg svært godt for å formidle ulike stemmer og perspektiver knyttet til en rolle, en tekst eller et fagstoff. Erfaringene ble en inngang til samtale om elevers, 
studenters og læreres identitetsarbeid både innenfor og utenfor klasserommet. Hvordan virker ulike elevroller på læring, læringsmiljø og klasseledelsesstrategier?

Studentenes ytringer i denne kategorien fremhever betydningen av utprøving og trening gjennom ulike medier. Både muntlig fortelling, poetiske lister og dramatisering blir nevnt: At ved å vcere en annen får jeg en innsikt i andre sin tankegang, tenke nytt om verden. Det at vi fikk bruke fortelling, skriveroller, og forskjellige kroppsøvelser overrasket meg, jeg har så lite repertoar og skulle ønske jeg kunne mer (Norsk G2,15). Gjennom at de selv fikk erfare verdien av symbolske og poetiske medier, ønsker de å bruke slike metoder i egen undervisning. En hindring for å utvikle eget formidlingsrepertoar ble forklart som at utdanningen ikke prioriterte opplæring og trening i praktiske ferdigheter; Vi larer ikke å fortelle eller å formidle på varierte måter. Ferdighetstrening blir ikke sett på som viktig i utdanningen (Norsk, G1,15). En tolkning av disse utsagnene er at erfaringene fra narrative og poetiske fiksjonsformer skaper motivasjon for å adaptere formidlingsformene til egen praksis, samtidig som flere uttrykker frustrasjon for at ferdighetstrening ikke prioriteres i utdanningen.

Selv om flere studenter vurderer opplæringen i ferdigheter og formidling som mangelfull, understreket flere studenter at de ønsket å overføre erfaringen fra fiksjonsformen til egen didaktisk praksis. Spesielt studentene fra norsk vurderer poetiske og narrative fiksjonsformer som svært viktig for å få til tilpasset opplæring: Jeg skjønner at det er sammenheng mellom å kunne et fag og det å ta didaktiske valg som kan åpne opp for tilpasset opplcering. Fortelling, bilde, musikk, litteratur virker forskjellig i forhold til det jeg ønsket at eleven skulle lcere. Bruk av kunst aktiviserer flere sanser og følelser. Kombinerer kropp og tanke på en måte. (Norsk, G2, 15). Erfaringene blir av flere et utgangspunkt for ordinær praksis: Blir spennende å se hvilke artefakter og arbeidsformer praksislcererne kommer til å bruke (Mat, G4, 15). En annen student sier at: Dette motiverte meg mer til å prøve ut de forskjellige metodene i praksis (Mat., G4,15). Poetiske og narrative medier blir av flere forstått som en forutsetning for didaktisk variasjon og for å få til tilpasset opplæring: ...nå har jeg flere metoder å starte en time på, og gjennom de forskjellige oppstartsformene så jeg flere muligheter til å differensiere undervisningen (Norsk, G1, 15). Verkstedet har bidratt til å åpne for nye måter å tenke didaktikk på, spesielt med tanke på tilpassa opplæring (Mat, G3, 15). Didaktisk variasjon ble som tidligere nevnt koblet til simuleringene. Min tolkning er at simuleringer i kombinasjon med narrative og poetiske fiksjonsformer ser ut til å bidra til didaktisk variasjon, noe som av flere studenter knyttes til tilpasset opplcering og klasseledelse (tematisk utgangspunkt for casen). Samtidig førte studentenes erfaring med narrative og poetiske fiksjonsformer til at de kritiserte lærerutdanningen for å nedprioritere ferdighetstrening og estetiske uttrykksformer.

Flere studenter uttaler at de gjennom poetiske og narrative fiksjonsformer kunne bruke erfaringer og følelser fra egen skolegang, barndom og 
identitetsarbeid. De vurderer slike opplevelser som viktige for å koble følelser til lærestoffet, noe som er grunnleggende for å kunne identifisere seg med ulike elevroller i klasserommet. Gjennom å skrive listene som meg selv som ungdom kjente jeg på hvor mye energi jeg hadde brukt på å sikre meg en plass i det sosiale hierarkiet på skolen (Norsk, G2, 15). En annen student sier at; Jeg visste at jeg ble utestengt fra gjengen hvis jeg var for flink (Norsk, G2, 15). Fiksjonserfaringene kan tolkes som en inngang til å leve seg inn i, tenke og iscenesette ulike roller. Et slikt perspektivbytte kan tolkes som utvikling av studentenes evne til å forstå hva andre mennesker tenker og føler. Min tolkning av studentuttalelsene kan oppsummeres i tre punkter:

1. Analysen viser at studentenes erfaringer med poetiske og narrative fiksjonsformer motiverer til å videreutvikle eget formidlingsrepertoar og en didaktisk verktøykasse i ordinær praksis.

2. På samme måte som refleksive fiksjonsformer kan poetiske og narrative fiksjonsformer bidra til at studentene lever seg inn i, tenker og samarbeider om å gi form til ulike roller og perspektiver. Erfaringene kobler følelser og kollektive erfaringer på læringsarbeidet, noe som synes viktig for empatisk tenkning og handling.

I siste avsnitt oppsummeres hvordan studentenes fiksjonserfaringer bidro til refleksjon og sammenheng mellom praktisk lærerarbeid og teoretiske perspektiver i utdanningen.

\section{Avsluttende drøfting: Fiksjon som medierende redskaper i grunnskolelærerutdanningen}

Jeg har i denne artikkelen analysert datamateriale fra undervisning i grunnskolelærerutdanningen. Analysen viser eksempler på hvordan en gruppe lærerstudenters fiksjonserfaringer kan bidra til refleksjon på tvers av praktiske og teoretiske perspektiver i grunnskolelærerutdanningen. Ved å forstå fiksjon som et medierende redskap i en undervisningskontekst antyder studien hvordan fiksjonsformene rammer inn og iscenesetter studentenes forkunnskaper, praktiske og didaktiske ferdigheter, følelser og empati. Analysen viser eksempler på hvordan tre fiksjonsformer har ulike epistemologiske implikasjoner, og at hvilke fiksjonsformer og medier man velger virker inn på hvilke former for kunnskaper, erfaringer og refleksjoner som settes i spill (Allern, 2003; Rasmussen, 2013; Østern, 2014). Mens simulering gir mulighet til å prøve ut og trene på praktisk lærerarbeid, bidrar refleksive fiksjonsformer til sammenheng mellom et fagspråk og praksis. Erfaringer med å forestille seg og dekode en situasjon gjennom et annet perspektiv enn sitt eget, ser ut til å bidra til at studentene lettere identifiserer seg med, inkluderer og diskuterer roller og 
perspektiver som kan synes fremmed eller ukjent fra egen skoletid og forforståelse (Dale \& Høy Hansen, 1998, s. 381; Østrem, 2009). Studentene får mulighet til å trene både språk, tanke og handling, slik at nye begreper, narrativer og perspektiver blir implementert. Erfaringer fra arbeidet med narrative og poetiske fiksjonsformer vurderes som en mulighet til å samarbeide om å gi form til studentenes forforståelse. Mediets form, logikk og språk bidrar til å mediere og formgi kunnskaper og erfaringer som finnes både i eget liv og i læringsfelleskapet/studentgruppen. (Barone \& Eisner, 2012; Dewey, 2005, s. 244). Poetiske og narrative fiksjonsformer muliggjør derfor en transformasjon fra hverdagsspråk og egen forforståelse til en kollektiv, symbolsk tolkning som involverer kropp, følelser og tanker (Dewey, 2005; Rasmussen, 2013; Rasmussen \& Gjærum, 2012; Rasmussen \& Kristoffersen, 2014). Disse erfaringene motiverte studentene til å videreutvikle sitt eget formidlingsrepertoar og sin egen didaktiske verktøykasse, noe som flere av dem mente blir mangelfullt ivaretatt i utdanningen. Selv om analysen viser eksempler på hva som skjer i profesjonsverkstedet og hvordan studentene reflekterer over fiksjonserfaringene i etterkant, sier den ikke noe om hvilke implikasjoner erfaringene har for studentenes arbeid i ordinær praksis, noe som kunne vært interessant å undersøke i videre forskning. Det kan se ut som fiksjonserfaringene fører til at studentene zoomer inn og ut av det tematiske utgangpunktet, som i denne casen er klasseledelse og tilpasset opplæring. Hvordan fiksjonsformer og andre medierende redskaper virker sammen i et undervisningsforløps dramaturgi, er et utgangspunkt for en ny studie med datamateriale fra profesjonsverkstedet (2017).

Som nevnt innledningsvis i denne artikkelen, viser forskning at det er høye krav til lærerutdanningen og at studentene ofte ønsker seg mer av hver enkelt lærerutdanner enn det som kanskje er realistisk eller ønskelig (Ulvik \& Smith, 2016). Kravene om integrasjon vil kanskje være mer overkommelige hvis lærerutdannere arbeider i team som har kjennskap til ulike fag, forskning og oppdatert praktisk lærerarbeid. Et lærerteam med ulike kvaliteter vil sammen kunne utvikle, utfordre og forske på egen praksis (Ulvik \& Smith, 2016). Arbeidet i profesjonsverkstedet er et eksempel på en slik arena. Et resultat av dette arbeidet er at fiksjonens grenseoverskridende kvaliteter vil benyttes og videreutvikles i vårt lokale arbeid med profesjonsverkstedet. En motivasjon - og tenk hvis det skulle skje - er at arbeidet også kan ha betydning for utvikling av undervisning og lærerutdanning i fremtiden.

\section{Referanser}

Allern, T.-H. (2003). Drama og erkjennelse: En undersøkelse av forholdet mellom dramaturgi og epistemologi i drama og dramapedagogikk (Doktoravhandling). NTNU, Trondheim.

Barone, T., \& Eisner, E. W. (2012). Arts based research. Los Angeles, Calif.: Sage. 
Boaler, J. (2016). Mathematical mindsets: Unleashing students' potential through creative math, inspiring messages, and innovative teaching. San Francisco, Calif.: Jossey Bass Publishers.

Bolton, G. (1984). Drama as education : an argument for placing drama at the centre of the curriculum. Harlow: Longman.

Braaten, L. T., \& Erstad, O. (2000). Film og pedagogikk Dialog og refleksjon i møte med film. Oslo: Norsk filminstitutt.

Børresen, B. (2016). Samtalen i klasserommet - samtale og læring. I K. Kverndokken (Red.), 101 måter å fremme muntlige ferdigheter på: Om muntlig kompetanse og muntlighetsdidaktikk (s. 89-101). Bergen: Fagbokforl.

Dale, E. L., \& Høy Hansen, I. (1998). Pcedagogik og professionalitet. Århus: Klim.

Dewey, J. (2005). Art as experience. New York: Berkley Publishing Group. (Opprinnelig utgitt 1934).

Fauskanger, J., \& Mosvold, R. (2014). Innholdsanalysens muligheter i utdanningsforskning. Norsk pedagogisk tidsskrift, 98(2), 127-139.

Fischer-Lichte, E. (2008). The transformative power of performance: a new aesthetics. London: Routledge.

Følgegruppen for lærerutdanningsreformen. (2015). Grunnskulelcrarutdanningane etter fem år: Status, utfordringar og vegar vidare: Rapport nr 5. Stavanger: Følgjegruppa for lærarutdanningsreforma.

Gerring, J. (2007). Case study research: principles and practices. Cambridge: Cambridge University Press.

Gladsø, S., Gjervan, E. K., Hovik, L., \& Skagen, A. (2005). Dramaturgi: forestillinger om teater. Oslo: Universitetsforlaget.

Grimen, H. (2008). Profesjon og kunnskap. Oslo: Universitetsforlaget.

Grossman, P., Hammerness, K., \& McDonald, M. (2009). Redefining teaching, re-imagining teacher education. Theory and Practice, 15(2), 273-289. doi:

10.1080/13540600902875340

Haapasaari, A., Engeström, Y., \& Kerosuo, H. (2014). The emergence of learners’ transformative agency in a Change Laboratory intervention. Journal of Education and Work, 29(2), 1-31. doi: 10.1080/13639080.2014.900168

Hammerness, K. (2012). A comparative study of three key features in the design and practice of teacher education in the United States and Norway. Acta didactica Norge, 6(1), 1-14. Hentet fra https://journals.uio.no/index.php/adno/article/view/1088

Haug, P. (2013). Kva skal til for å endre lærarutdanninga? Bedre skole.

Heggstad, K. M., Eriksson, S. A., \& Rasmussen, B. (2013). Teater som danning. Bergen: Fagbokforl.

Horntvedt, M., \& Arnseth, H. C. (2013). On the bridge to learn: Analysing the social organization of nautical instruction in a ship simulator. International Journal of Computer-Supported Collaborative Learning, 8(1), 89-112. doi: 10.1007/s11412-0139166-3

Hsieh, H.-F., \& Shannon, S. E. (2005). Three approaches to qualitative content analysis. Qualitative Health Research, 15(9), 1277-1288.

Kjølner, T. (2007). Teatralitet og performativitet. Peripeti - Tidskrift for dramaturgiske studier(7), 7-37.

Krøgholt, I. (2001). Performance og dramapcedagogik: et krydsfelt. Århus: Institutet.

Kvernbekk, T. (2005). Pedagogisk teoridannelse : insidere, teoriformer og praksis. Bergen: Fagbokforlaget.

Lampert, M. (2001). Teaching problems and the problems of teaching. New Haven: Yale University Press. 
Lindstøl, F. (2014). Mål tid(en): Dramaturgiske og kunnskapsteoretiske implikasjoner til en pragmatisk estetikk. InFormation - Nordic Journal of Art and Research, 3(2), 110-128. Hentet fra http://www.artandresearch.info/

Lindstøl, F., \& Bakke, J. O. (2016). 17 muntlighetsgrep. I K. Kverndokken (Red.), 101 måter å fremme muntlige ferdigheter på : om muntlig kompetanse og muntlighetsdidaktikk (37 s. ). Oslo: Fagbokforlaget.

Lindstøl, F., Bakke, J. O., \& Moe, M. (2015). As if - om profesjonsverksted i GLU. I E. K. Høihilder \& O. A. Gulbrandsen (Red.), Pedagogikk og elevkunnskap i grunnskolelcererutdanningen: PEL i GLU (s. 305-314). Oslo: Gyldendal akademisk.

Munthe, E., \& Haug, P. (2010). En integrert, profesjonsrettet og forskningsbasert grunnskolelærerutdanning. Norsk pedagogisk tidsskrift, 94(3), 188-202.

Munthe, E., \& Rogne, M. (2015). Research based teacher education. Teaching and Teacher Education, 46, 17-24. doi: 10.1016/j.tate.2014.10.006

Neelands, J., Goode, T., \& Mørch, J. (2000). Drama i praksis: teori, ideer og metoder. Gråsten: Drama.

Qvortrup, A., \& Keiding, T. B. (2014). Undervisningens vidensdomæner: Erfaring, didaktik og uddannelsesvidenskab. Dansk Universitetspæedagogisk Tidsskrift, 9(17), 1-14.

Rasmussen, B. (2008). Beyond imitation and representation: extended comprehension of mimesis in drama education. Research in Drama Education: The Journal of Applied Theatre and Performance, 13(3), 307-319. doi: 10.1080/13569780802410673

Rasmussen, B. (2013). Fra erfaring til refleksiv kunnskap: Sentrale prinsipper i drama og praksisledet forskning. . I A.-L. Østern, G. Stavik-Karlsen \& E. A. Aalberg (Red.), Kunstpedagogikk og kunnskapsutvikling (s. 261-270). Oslo: Universitetsforl.

Rasmussen, B., \& Gjærum, R. G. (2012). Vitenskapsteori og kunnskapssyn i anvendt drama/teaterforskning. I R. G. Gjærum \& B. Rasmussen (Red.), Forestilling, framføring, forskning: Metodologi i anvendt teaterforskning (s. 7-20). Trondheim: Akademika.

Rasmussen, B., \& Kristoffersen, B. (2014). Mye på spill: Teater som danningspraksis i skolen. Bergen: Fagbokforl.

Skjervheim, H. (1992). Filosofi og dømmekraft. Oslo: Universitetsforlaget.

Säljö, R. (2001). Lœring i praksis: et sosiokulturelt perspektiv. Oslo: Cappelen akademisk.

Ulvik, M., \& Smith, K. (2016). Å undervise om å undervise - Lærerutdanneres kompetanse sett fra deres eget og fra lærerstudenters perspektiv. Uniped, 9(01).

Vygotskij, L. S. (1986). Thought and language. Cambridge, Mass: MIT Press. (Oversatt til engelsk og revidert av Alex Kozulin.)

Wittek, L. (2012). Lcring i og mellom mennesker: en innføring i sosiokulturelle perspektiver. Oslo: Cappelen Damm akademisk.

Østern, A.-L. (2014). Det uavsluttede. I A.-L. Østern (Red.), Dramaturgi i en didaktisk kontekst (s. 169-174). Bergen: Fagbokforlaget.

Østrem, S. (2009). Lærerutdanningens bidrag i læreres kunnskapsutvikling. Nordic Studies in Education, 29(4), 369-383. 